УДК 633.58:633.11«312»

(C) 2016

Антал Т. В., Гарбар Л. А., Малеончук О. В., кандидати сільськогосподарських наук, Корпан А. С., Трет'як Д. А., бакалаври

Національний університет біоресурсів і природокористування України

\title{
ПОЛЬОВА СХОЖІСТЬ ТА УРОЖАЙНІСТЬ ПШЕНИЦ ТВЕРДОЇ ЯРОЇ ТА М'ЯКОЇ ПРИ ЗАСТОСУВАННІ МІНЕРАЛЬНИХ ДОБРИВ В УМОВАХ ЛІСОСТЕПУ УКРАЇНИ
}

\section{Рецензент - кандидат сільськогосподарських наук О. В. Завадська}

\begin{abstract}
Висвітлено результати досліджень щзодо вивчення впливу мінеральних добрив під пшеницю тверду та м'яку яру на польову схожість та урожайність за вирощування ї̈ в умовах Лісостепу Украӥни. Встановлено, щзо в Лісостепу Украӥни на чорноземі глибокому малогумусному та чорноземі опідзоленому польова схожість рослин залежить від погодних умов, попередника та системи удобрення. Доведено, щзо у варіантах із внесенням фосфорних та калійних добрив польова схожість насіння була на 4-5\% вищою порівняно з варіантами без внесення добрив. Зі збільшенням норми висіву насіння з 3,0 млн ит./2а до 7,0 млн шт./га польова схожість насіння пшениці ярої знижується в середньому на 0,4-1,2\%.
\end{abstract}

Ключові слова: урожайність, польова схожість, удобрення, норма висіву, попередник, пшениия яра.

Постановка проблеми. Зернова галузь є базою стабільного розвитку галузей АПК. Незважаючи на те, що грунтово-кліматичні умови сприяють отриманню високих врожаїв, ця галузь не забезпечує внутрішніх потреб та експорту зерна високої якості. Пшениця яра стає важливою стратегічною зерновою культурою у вирішенні проблеми виробництва високоякісного зерна [5]. Сучасні сорти пшениці ярої мають високий потенціал урожайності (в дослідах до 5,0-5,5 т/га, в умовах виробництва - близько 3,0-3,5 т/га). Проте середня урожайність за останні роки в умовах Лісостепу становила лише 2,0-2,5 т/га. Одна 3 причин невисокої врожайності - недостатнє вивчення умов ефективного застосування добрив 3 урахуванням рівня зволоження та забезпеченості грунту елементами живлення. Виявлення закономірностей дії мінеральних добрив на родючість грунту та врожайність сільськогосподарських культур - важлива умова для розробки науково обгрунтованої системи удобрення [3, 1].

Аналіз основних досліджень i публікацій, у яких започатковано розв'язання проблеми. Найбільш сприятливі умови для досягнення високої продуктивності рослин, польової схожості, а також для підтримання родючості грунту на потрібному рівні створюються за повного забезпечення їх елементами живлення. На польову схожість насіння, перш за все, впливає вологозабезпеченість та температура грунту, а також агротехнічні заходи: строк сівби та рівень мінерального живлення рослин [4].

Після посівних якостей насіння, зокрема такого показника, як лабораторна схожість, польова схожість насіння $\epsilon$ практично першим реальним фактором формування продуктивності посіву. В польових умовах одночасно діє комплекс факторів, які можуть сприяти її підвищенню або зниженню, проте основними $\epsilon$ температура та вологість грунту. Наприклад, шкідники, інфікованість насіння і грунту хворобами, фізичний стан грунту в тому випадку, коли температура і вологість грунту несприятливі для одержання швидких дружніх сходів і поява їх затримується, можуть призвести до суттєвого зниження польової схожості [1].

Метою та завданням досліджень передбачалось встановлення в умовах північної та північнозахідної частинах Лісостепу України особливостей формування продуктивності та рівня польової схожості сортів пшениці ярої залежно від попередника, норми висіву та системи удобрення.

Матеріали і методи досліджень. Польові дослідження проводились у ВП НУБіП України «Агрономічна дослідна станція» протягом 20122014 років у стаціонарному досліді кафедри рослинництва. Досліджувались два сорти пшениці твердої ярої Ізольда та Чадо. Мінеральні добрива вносили за схемою:

1) Контроль; 2) $\mathrm{P}_{60} \mathrm{~K}_{60}$; 3) $\mathrm{N}_{30 \text { п }}+\mathrm{N}_{30 \mathrm{IV}}$;

4) $\mathrm{N}_{30} \mathrm{P}_{30} \mathrm{~K}_{30}$; 5) $\mathrm{N}_{30} \mathrm{P}_{30} \mathrm{~K}_{30}+\mathrm{N}_{30 \mathrm{IV}}$;

6) $\mathrm{P}_{60} \mathrm{~K}_{60}+\mathrm{N}_{30 \text { III }}+\mathrm{N}_{30 \mathrm{IV}}$; 7) $\mathrm{P}_{60} \mathrm{~K}_{60}+\mathrm{N}_{30 \mathrm{IV}}+\mathrm{N}_{30 \mathrm{x}}$;

8) $\mathrm{N}_{60} \mathrm{P}_{60} \mathrm{~K}_{60}$; 9) $\left.\mathrm{N}_{60} \mathrm{P}_{60} \mathrm{~K}_{60}+\mathrm{N}_{30 I V} ; 10\right) \mathrm{N}_{90} \mathrm{P}_{90} \mathrm{~K}_{90}$;

11) $\mathrm{N}_{90} \mathrm{P}_{90} \mathrm{~K}_{90}+\mathrm{N}_{301}$; 12) $\left.\mathrm{N}_{120} \mathrm{P}_{120} \mathrm{~K}_{120} ; 13\right) \mathrm{N}_{120} \mathrm{P}_{120} \mathrm{~K}_{120}$ $+\mathrm{N}_{30 \mathrm{IV}}$.

Дослідження з питань впливу попередників, норми висіву та системи удобрення на урожайність $\mathrm{i}$ польову схожість сортів пшениці м'якої ярої проводили шляхом закладання польового досліду, відповідно до загальноприйнятих методик, за чотирифакторною схемою (табл. 1). 


\section{1. Схема досліду}

\begin{tabular}{|c|c|c|c|}
\hline Фактор А. Сорт & $\begin{array}{c}\text { Фактор В. } \\
\text { Попередники }\end{array}$ & $\begin{array}{c}\text { Фактор С. } \\
\text { Удобрення }\end{array}$ & $\begin{array}{c}\text { Фактор D. } \\
\text { Норма висіву, млн шт./га } \\
\text { схожого насіння }\end{array}$ \\
\hline & Цукрові буряки & & 3,0 \\
Рання 93 & Картопля & $\mathrm{N}_{0} \mathrm{P}_{0} \mathrm{~K}_{0}$ (контроль) & 4,0 \\
Колективна 3 & $\mathrm{N}_{30} \mathrm{P}_{30} \mathrm{~K}_{30}$ & 5,0 \\
& Озима пшениця & $\mathrm{N}_{30} \mathrm{P}_{60} \mathrm{~K}_{60}+\mathrm{N}_{30}(\mathrm{III})$ & 6,0 \\
& + післяжнивно & $\mathrm{N}_{30} \mathrm{P}_{90} \mathrm{~K}_{90}+\mathrm{N}_{30}$ (III)+N $\mathrm{N}_{30}$ (VIII) & 7,0 \\
\hline
\end{tabular}

\section{2. Польова схожість насіння пшениці твердої ярої}

\begin{tabular}{|c|c|c|c|c|c|c|}
\hline \multirow[b]{2}{*}{ Варіант досліду } & \multicolumn{2}{|c|}{$2012 \mathrm{p}$} & \multicolumn{2}{|c|}{2013 p. } & \multicolumn{2}{|c|}{$2014 \mathrm{p}$} \\
\hline & 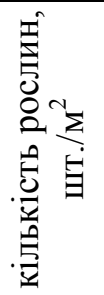 & 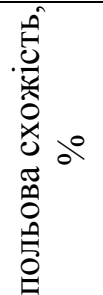 & 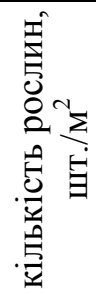 & 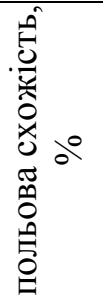 & 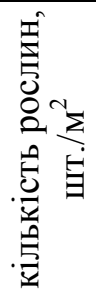 & $\begin{array}{l}\hat{0} \\
\hat{0} \\
0 \\
0 \\
0 \\
0 \\
0 \\
0 \\
0 \\
0 \\
0 \\
0 \\
0 \\
0 \\
0 \\
0\end{array}$ \\
\hline \multicolumn{7}{|c|}{ Ізольда } \\
\hline Контроль & 398 & 79,6 & 376 & 70,4 & 404 & 80,8 \\
\hline $\mathrm{N}_{30 I I}+\mathrm{N}_{30 \mathrm{IV}}$ & 400 & 80,0 & 380 & 71,2 & 403 & 81,6 \\
\hline $\mathrm{N}_{30} \mathrm{P}_{30} \mathrm{~K}_{30}$ & 408 & 81,6 & 374 & 70,0 & 408 & 81,6 \\
\hline $\mathrm{N}_{30} \mathrm{P}_{30} \mathrm{~K}_{30}+\mathrm{N}_{30 \mathrm{IV}}$ & 408 & 81,6 & 376 & 70,4 & 406 & 81,2 \\
\hline $\mathrm{P}_{60} \mathrm{~K}_{60}$ & 406 & 81,2 & 386 & 72,4 & 420 & 84,0 \\
\hline $\mathrm{P}_{60} \mathrm{~K}_{60}+\mathrm{N}_{30 \mathrm{IV}}+\mathrm{N}_{30 \mathrm{x}}$ & 408 & 81,6 & 390 & 73,2 & 423 & 84,6 \\
\hline $\mathrm{P}_{60} \mathrm{~K}_{60}+\mathrm{N}_{30 I I}+\mathrm{N}_{30 \mathrm{IV}}$ & 404 & 80,8 & 392 & 73,6 & 425 & 85,0 \\
\hline $\mathrm{N}_{60} \mathrm{P}_{60} \mathrm{~K}_{60}$ & 402 & 80,4 & 367 & 68,6 & 424 & 84,4 \\
\hline $\mathrm{N}_{60} \mathrm{P}_{60} \mathrm{~K}_{60}+\mathrm{N}_{30 \mathrm{IV}}$ & 400 & 80,0 & 368 & 68,8 & 426 & 85,2 \\
\hline $\mathrm{N}_{90} \mathrm{P}_{90} \mathrm{~K}_{90}$ & 396 & 79,2 & 364 & 68,0 & 408 & 81,6 \\
\hline $\mathrm{N}_{90} \mathrm{P}_{90} \mathrm{~K}_{90}+\mathrm{N}_{30 \mathrm{IV}}$ & 398 & 79,6 & 363 & 67,8 & 410 & 82,0 \\
\hline $\mathrm{N}_{120} \mathrm{P}_{120} \mathrm{~K}_{120}$ & 391 & 78,2 & 360 & 67,2 & 404 & 80,8 \\
\hline $\mathrm{N}_{120} \mathrm{P}_{120} \mathrm{~K}_{120}+\mathrm{N}_{30 \text { IV }}$ & 394 & 78,8 & 363 & 67,8 & 406 & 81,2 \\
\hline $\mathrm{HIP}_{05}$ & & 1,5 & & 1,2 & & 1,6 \\
\hline \multicolumn{7}{|c|}{ Чадо } \\
\hline Контроль & 380 & 76,0 & 368 & 68,8 & 385 & 77,0 \\
\hline $\mathrm{N}_{30 I I}+\mathrm{N}_{30 I V}$ & 382 & 76,4 & 370 & 69,2 & 389 & 77,8 \\
\hline $\mathrm{N}_{30} \mathrm{P}_{30} \mathrm{~K}_{30}$ & 392 & 78,4 & 371 & 69,4 & 403 & 80,6 \\
\hline $\mathrm{N}_{30} \mathrm{P}_{30} \mathrm{~K}_{30}+\mathrm{N}_{30 \mathrm{IV}}$ & 390 & 78,0 & 372 & 69,6 & 408 & 81,6 \\
\hline $\mathrm{P}_{60} \mathrm{~K}_{60}$ & 395 & 79,0 & 374 & 70,0 & 416 & 82,4 \\
\hline $\mathrm{P}_{60} \mathrm{~K}_{60}+\mathrm{N}_{30 \mathrm{IV}}+\mathrm{N}_{30 \mathrm{x}}$ & 397 & 79,4 & 377 & 70,6 & 412 & 83,2 \\
\hline $\mathrm{P}_{60} \mathrm{~K}_{60}+\mathrm{N}_{30 \mathrm{II}}+\mathrm{N}_{30 \mathrm{IV}}$ & 395 & 79,0 & 378 & 70,8 & 414 & 82,8 \\
\hline $\mathrm{N}_{60} \mathrm{P}_{60} \mathrm{~K}_{60}$ & 386 & 77,2 & 366 & 68,4 & 386 & 77,2 \\
\hline $\mathrm{N}_{60} \mathrm{P}_{60} \mathrm{~K}_{60}+\mathrm{N}_{30 \mathrm{IV}}$ & 388 & 77,6 & 364 & 68,0 & 389 & 77,8 \\
\hline $\mathrm{N}_{90} \mathrm{P}_{90} \mathrm{~K}_{90}$ & 378 & 75,6 & 359 & 67,0 & 382 & 76,4 \\
\hline $\mathrm{N}_{90} \mathrm{P}_{90} \mathrm{~K}_{90}+\mathrm{N}_{30 \mathrm{IV}}$ & 376 & 75,2 & 357 & 66,6 & 386 & 77,2 \\
\hline $\mathrm{N}_{120} \mathrm{P}_{120} \mathrm{~K}_{120}$ & 375 & 75,0 & 348 & 64,8 & 380 & 76,0 \\
\hline $\mathrm{N}_{120} \mathrm{P}_{120} \mathrm{~K}_{120}+\mathrm{N}_{30 \text { IV }}$ & 371 & 74,2 & 346 & 57,4 & 378 & 75,6 \\
\hline $\mathrm{HIP}_{05}$ & & 1,3 & & 1,5 & & 1,3 \\
\hline
\end{tabular}




\section{СІЛЬСЬКЕ ГОСПОДАРСТВО. РОСЛИННИЦТВО}

Результати досліджень. Нашими дослідженнями доведено: польова схожість насіння сорту Чадо (77,0; 72,5; 78,9 \% у 2012, 2013, 2014 роках) була дещо нижчою порівняно із сортом Ізольда (80,2; 74,7; 82,6 \% у 2012, 2013, 2014 роках) (табл. 2, 3).

Польова схожість насіння пшениці ярої Рання 93 в усі роки досліджень була вища і становила 80,7-84,2 \%, залежно від факторів досліду, порівняно з сортом Колективна 3 - 76,8-80,2 \%. Вища польова схожість насіння пшениці ярої відмічена за сівби після картоплі.

У сорту Колективна 3 на варіанті без внесення мінеральних добрив за норми висіву 5,0 млн шт./га польова схожість залежно від попередника становить: після цукрових буряків - 77,9 \%, після картоплі - 79,0 \%, після озимої пшениці + післяжнивно гірчиця біла $-77,0 \%$, у сорту Рання 93 - 82,0 \%; 82,8 \%; 81,0 \% відповідно.

Зі збільшенням норми висіву насіння з 3,0 млн шт./га до 7,0 млн шт./га польова схожість насіння пшениці ярої знижується в середньому на 0,4-1,2\%. Порівнюючи два досліджувані сорти щодо урожайності, варто зазначити, що більш урожайним був сорт Ізольда. В середньому за роки досліджень на варіанті без внесення добрив сорт Ізольда забезпечив урожайність зерна на рівні 2,43 т/га, тоді як сорт Чадо - на 0,6 т/га менше. Найменший приріст урожайності в обох досліджуваних сортів був за внесення $\mathrm{P}_{60} \mathrm{~K}_{60}$, що свідчить про позитивну реакцію цієї культури на азотні добрива.

\section{3. Польова схожість насіння пиениці м'якої ярої (середнє 2012-2014 рр.)}

\begin{tabular}{|c|c|c|c|c|c|c|}
\hline \multirow{4}{*}{$\begin{array}{c}\text { Норма висіву, } \\
\text { млн штук/га }\end{array}$} & \multicolumn{6}{|c|}{ Сорт } \\
\hline & \multicolumn{3}{|c|}{ Колективна 3} & \multicolumn{3}{|c|}{ Рання 93} \\
\hline & \multicolumn{6}{|c|}{ Попередник } \\
\hline & $\begin{array}{l}\text { цукрові } \\
\text { буряки }\end{array}$ & картопля & $\begin{array}{c}\text { озима пше- } \\
\text { ниця + піс- } \\
\text { ляж. гір. біла }\end{array}$ & $\begin{array}{c}\text { цукрові } \\
\text { буряки }\end{array}$ & картопля & $\begin{array}{c}\text { озима пше- } \\
\text { ниця + піс- } \\
\text { ляж. гір. біла }\end{array}$ \\
\hline \multicolumn{7}{|c|}{$\mathrm{N}_{0} \mathrm{P}_{0} \mathrm{~K}_{0}$} \\
\hline 3,0 & 78,2 & 79,1 & 77,0 & 82,1 & 83,0 & 81,2 \\
\hline 4,0 & 78,0 & 79,0 & 77,0 & 82,0 & 82,9 & 81,0 \\
\hline 5,0 & 77,9 & 79,0 & 77,0 & 82,0 & 82,8 & 81,0 \\
\hline 6,0 & 77,7 & 78,9 & 76,9 & 81,8 & 82,6 & 80,8 \\
\hline 7,0 & 77,5 & 78,9 & 76,8 & 81,7 & 82,4 & 80,7 \\
\hline \multicolumn{7}{|c|}{$\mathrm{N}_{30} \mathrm{P}_{30} \mathrm{~K}_{30}$} \\
\hline 3,0 & 78,5 & 79,4 & 77,3 & 82,3 & 83,3 & 81,3 \\
\hline 4,0 & 78,2 & 79,2 & 77,3 & 82,2 & 83,1 & 81,1 \\
\hline 5,0 & 78,0 & 79,2 & 77,1 & 82,2 & 83,0 & 81,1 \\
\hline 6,0 & 77,9 & 78,9 & 77,0 & 81,9 & 82,8 & 80,9 \\
\hline 7,0 & 77,6 & 78,7 & 76,9 & 81,8 & 82,8 & 80,7 \\
\hline \multicolumn{7}{|c|}{$\mathrm{N}_{30} \mathrm{P}_{60} \mathrm{~K}_{60}+\mathrm{N}_{30 \text { (III) }}$} \\
\hline 3,0 & 79,0 & 79,6 & 77,6 & 82,6 & 83,8 & 81,5 \\
\hline 4,0 & 79,0 & 79,5 & 77,5 & 82,4 & 83,6 & 81,5 \\
\hline 5,0 & 78,7 & 79,3 & 77,5 & 82,2 & 83,6 & 81,3 \\
\hline 6,0 & 78,6 & 79,0 & 77,2 & 82,0 & 83,2 & 81,0 \\
\hline 7,0 & 78,4 & 78,9 & 77,1 & 81,7 & 83,0 & 80,8 \\
\hline \multicolumn{7}{|c|}{$\mathrm{N}_{30} \mathrm{P}_{90} \mathrm{~K}_{90}+\mathrm{N}_{30 \text { (III) }+30 \text { (VIII) }}$} \\
\hline 3,0 & 79,4 & 80,2 & 79,0 & 83,3 & 84,2 & 82,1 \\
\hline 4,0 & 79,2 & 80,0 & 77,8 & 83,1 & 84,0 & 82,0 \\
\hline 5,0 & 79,1 & 79,6 & 77,7 & 82,8 & 83,9 & 81,7 \\
\hline 6,0 & 78,9 & 79,4 & 77,4 & 82,6 & 83,7 & 81,5 \\
\hline 7,0 & 78,6 & 79,1 & 77,0 & 82,2 & 83,3 & 81,2 \\
\hline
\end{tabular}




\section{СІЛЬСЬКЕ ГОСПОДАРСТВО. РОСЛИННИЦТВО}

За результатами наших досліджень продуктивність пшениці ярої по-різному формувалась залежно від попередника. Так, після цукрових буряків продуктивність пшениці ярої без внесення мінеральних добрив була на 0,2-1,3 т/га нижчою, ніж після картоплі. Збільшення норми мінеральних добрив NPK до 60-90 кг/га д.р. не сприяло зростанню врожайності.

Взаємодія норми висіву 3 добривами також суттєво впливала на продуктивність сортів пшениці ярої. Зі збільшенням норми висіву від 3,0 до 7,0 млн шт./га схожих насінин урожайність зростала в середньому на 0,2-1,4 т/га. Така залежність спостерігалася у всіх сортів, що вивчалися, та після всіх попередників як без удобрення, так iз внесенням $\mathrm{N}_{30} \mathrm{P}_{30} \mathrm{~K}_{30}$. У разі загущення посівів до 7,0 млн шт./га схожих насінин і удобренні $\mathrm{N}_{60} \mathrm{P}_{60} \mathrm{~K}_{60}$ та $\mathrm{N}_{90} \mathrm{P}_{90} \mathrm{~K}_{90}$ спостерігалось вилягання

\section{БІБЛІОГРАФІЯ}

1. Ефективність технологій вирощування ярої пшениці в західному Лісостепу // Зб. наук. праць Ін-ту землеробства УААН (спецвипуск) / [Свідерко М. С., Болехівський В. П., Тимків М. Ю., Кубишин С. Я.]. - К. : ЕКМО, 2004. - 212 c.

2. Оптимізація вирощування ярої пшениці в лівобережному Лісостепу України // Наукове видання. Мін. АПК, УААН Голов. упр. с.-г. і прод. Харківської ОДА. - Х. : Центр наук. забезп. АПВ Харків. обл., IP ім. В. Я. Юр'єва, 2003. -24 c.

3. Рекомендації по вирощуванню ярої пшениці пшениці ярої, проте було меншим у сорту Колективна 3.

Висновок. Оптимальною нормою добрив для пшениці ярої твердої в умовах Південного Лісо-

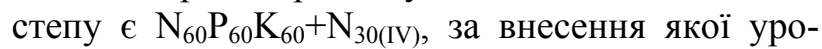
жайність сорту Ізольда порівняно до контролю збільшується у 2,5-2,9 рази, а сорту Чадо - 2,32,7 рази. Подальше підвищення норми добрив знижує урожайність обох сортів.

Мінеральні добрива підвищують урожайність пшениці ярої м'якої сорту Колективна 3 в умовах Північного Лісостепу залежно від елементів технології вирощування в середньому від 0,1 до 1,0 т/га. Внесення $\mathrm{N}_{30} \mathrm{P}_{30} \mathrm{~K}_{30}$ порівняно із варіантом без добрив сприяе зростанню врожайності на 15-16 \%, тоді як збільшення дози добрив до $\mathrm{N}_{60} \mathrm{P}_{60} \mathrm{~K}_{60}-$ у межах 4-15\%, у разі $\mathrm{N}_{90} \mathrm{P}_{90} \mathrm{~K}_{90}-$ тільки на 2-7\%.

в Лісостепу України / [Мельник С. І., Ситник В. П., Лазар Т. І., Войтов І. М., Козацький Д. В. та ін.]. Х. : [б.в.], 2006. -23 с.

4. Шевніков Д. М. Вплив мінеральних добрив на поживний режим грунту за вирощування пшениці твердої ярої / Д. М. Шевніков // Вісник Полтавської державної аграрної академії. - №2. 2012. - C. 203-206.

5. Юла В. М. Особливості технології вирощування ярої твердої і м'якої пшениці в умовах Лісостепу України : дис.... к.с.-г.н. : 06.01 .09 / В. М. Юла. - К., 1998. - 212 с. 